DOI: https://doi.org/10.32839/2304-5809/2020-12-88-69

удК 811.111'255.4

Шевченко М.Ю.

Донбаський державний педагогічний університет

\title{
ЗАСТОСУВАННЯ ІННОВАЦІЙНИХ ТЕХНОЛОГІЙ У ПРОЦЕСІ ВИКЛАДАННЯ АНГЛІЙСЬКОЇ МОВИ У ВИЩІЙ ШКОЛІ
}

Анотація. У статті розглянуто питання ролі інноваційних технологій в процесі підвищення мовних навичок англійської мови студентів вищої школи. Різні методи з використанням технологій 3 поліпшення чотирьох мовних навичок були детально розглянуті та охарактеризовані. Автором наголошено на тому, що інноваційні технології е невід'емною частиною процесу викладання і вивчення англійської мови. Інноваційні технології стали невід'ємною частиною процесу викладання і вивчення англійської мови. Вони допомагають студентам за коротший час оволодіти потрібними навичками для вільного використання англійської мови, а саме: навички аудіювання, читання, письма та комунікації. 3 огляду на всю важливість інноваційних технологій, слід зазначити, що центральне місце у процесі викладання займає особистість вчителя, який обирає, оцінюе і впроваджує нові технології. Таким чином, технології допомагають викладачеві вирішити велику кількість технічних питань, зробити урок цікавішим, але технології не можуть замінити викладача повністю. Перспективою для подальших досліджень може стати аналіз інших інноваційних тенденцій у процесі викладання англійської мови. Інноваційні технології стали невід'ємною частиною процесу викладання і вивчення англійської мови. Вони допомагають студентам за коротший час оволодіти потрібними навичками для вільного використання англійської мови, а саме: навички аудіювання, читання, письма та комунікації. 3 огляду на всю важливість інноваційних технологій, слід зазначити, що центральне місце у процесі викладання займає особистість вчителя, який обирає, оцінюе і впроваджуе нові технології. Таким чином, технології допомагають викладачеві вирішити велику кількість технічних питань, зробити урок цікавішим, але технології не можуть замінити викладача повністю. Перспективою для подальших досліджень може стати аналіз інших інноваційних тенденцій у процесі викладання англійської мови. Окремо визначена провідна роль особистості вчителя в освітньому процесі. Автором зазначено, що освітні та інноваційні процеси є невід'емними один від одного процесами. Ключові слова: навик, інновація, технологія, освіта, комунікація.

\section{Shevchenko Maryna}

Donbas State Teachers Training University

\section{THE USE OF INNOVATIONAL TECHNOLOGIES IN THE PROCESS OF TEACHING UKRAINIAN IN A HIGHER SCHOOL}

Summary. The article deals with the role of innovative technologies in the process of improving the language skills of English of students of higher education. Various methods using technologies to improve the four language skills have been thoroughly discussed and characterized. Such methods are very important for teaching process. The author emphasizes that innovative technologies are an integral part of the process of teaching and learning the English language. Innovative technologies have become an integral part of the process of teaching and learning the English language. They help students acquire the necessary skills to use the English language in a short time, such as: listening, reading, writing and communication skills. Given the importance of innovative technologies, it should be noted that the centrality in the teaching process is the personality of the teacher who selects, evaluates and implements new technologies. Thus, technology helps the teacher solve a lot of technical issues, make the lesson more interesting, but technology cannot replace the teacher completely. The prospect of further research may be to analyze other innovative trends in the English language teaching process. Innovative technologies have become an integral part of the process of teaching and learning the English language. They help students acquire the necessary skills to use the English language in a short time, such as: listening, reading, writing and communication skills. Given the importance of innovative technologies, it should be noted that the centrality in the teaching process is the personality of the teacher who selects, evaluates and implements new technologies. Thus, technology helps the teacher solve a lot of technical issues, make the lesson more interesting, but technologies cannot replace the teacher completely. The prospect of further research may be to analyze other innovative trends in the English language teaching process. The leading role of the teacher's personality in the educational process is defined separately. The author states that educational and innovation processes are inseparable processes.

Keywords: skill, innovation, technology, education, communication.

$\mathrm{B}^{\mathrm{c}}$ ступ. Інфрормащійне суспільство, що характеризується наявністю глобалізаційних процесів, технологізацією всіх галузей народного господарства, іншими властивими сучасній цивілізації тенденціями, обумовлює розвиток людини як головну мету, ключовий показник сучасного прогресу і висуває нові вимоги до освіти, адже саме освіта $є$ визначальним чинником політичної, соціально-економічної, культурної та на- укової життедіяльності людства. Інтеграція в европейський і світовий освітній простір, перехід до нових організаційних моделей упровадження інноваційних технологій, визначаються як важливі завдання процесу модернізації освіти.

Постановка проблеми. Поняття «інновація» увійшло в науку ще у XIX столітті і вживалося при вивченні змін у культурі на противагу поняттю «традищія». Тепер інновації розглядаються як пев- 
на стадія процесу соціальної зміни. Соціологія визначає інновацію «як комплексний процес створення, поширення і використання нового практичного засобу (нововведення) для задоволення людських потреб, а також пов'язані 3 цим нововведенням зміни у соціальному середовищі» $[1$, с. 25].

Методи та методики дослідження. Різні інноваційні технології буде порівняно та проаналізовано, виявляючи найедективніші засоби для провадження у процес вивчення української мови.

У зв'язку з розвитком інноваційних процесів та інноваційної діяльності, на початку XXI століття, з'являеться теорія освітньої інноватики, як наука про нововведення, у якій розкриваеться «суттевий зміст ключових понять даної теорії, таких як педагогічна інновація, освітня інновація, інноваційний освітній проект, інноваційна освітня діяльність, інноващійний навчальний заклад та ін.; умови здійснення інноваційної освітньої діяльності; параметри, показники та критерії оцінки педагогічних інновацій; принципи відбору педагогічно доцільних освітніх інновацій» [1, с. 3].

Інноващії, що застосовуються в освіті, називають освітніми інноваціями. На думку, С. Савченко освітня інновація - це процес створення, поширення і використання нових засобів (нововведень) для тих педагогічних проблем, які досі вирішувалися по-іншому [2, с. 51$]$.

Основними принципами, згідно яким здійснюеться інноваційна діяльність у навчальних закладах $е$ :

- принцип обов'язкового впливу інновації на кінцевий результат освітньої діяльності (застосування будь-якої освітньої інновації обов'язково приносить якісну зміну кінцевого результату навчального процесу);

- принцип обов'язкового впливу інновації на інтелектуальні, матеріальні і тимчасові витрати учасників освітнього процесу (використання будьякої інновації обов'язково вимагає застосування додаткових інтелектуальних, матеріальних і тимчасових витрат учасників освітнього процесу).

Актуальність дослідження обумовлена тим, що англійська мова $€$ надзвичайно важливою складовою системі сучасної освіти і науки, яка відкриває нові горизонти для учнів. На сьогоднішній день, англійська мова є глобально вживаним явищем практично в усіх галузях діяльності людини: науці, техніці, бізнесі, економіці і т.п. Цей фракт є причиною того, що на сьогоднішній день викладання української мови вважається найважливішим пріоритетом освітнього процесу [4, с. 36]. Такий стан створюе необхідність, того, що система освіти повинна реагувати на розвиток технологічних i наукових досягнень у сфрері викладання англійської мови та вчасно впроваджувати їх у процес навчання для швидкого розвитку навичок української мови у студентів, а також для підготовки компетентних трудових кадрів у цілому.

Метою статті $є$ визначення функцій інноваційних технологій у процесі викладання англійської мови у вищій школі.

Предметом дослідження є викладання англійської мови у рамках сучасного освітнього процесу.

Об'єктом дослідження є інноваційні технології, які застосовуються викладачем для підвищення ефективності і якості процесу викладання англійської мови.
Аналіз досліджень і публікацій. Інноващійні технології в освіті досліджувалися багатьма вченими, такими як: А. Савченко, Л. Даниленко, В. Бондар, В. Васильев, К. Роджерс, А. Маслоу та ін.

Результати та дискусіі. 3 появою нових технологій та інновацій у галузі освіти, процес викладання англійської мови у вищій школі зазнав змін у методології, методах і стилях викладання. Використання нових технологій у процесі викладання англійської мови є особливо важливим явищем для розвитку макролінгвістичних навичок. Технічні засоби дозволяють поєднувати усні і письмові форми нових лексичних одиниць за допомогою автентичних аудіо матеріалів, а також закріпити їх у процесі візуалізації, використовуючи проектори, відеоматеріали і т.п. Такі технології переносять «зовнішній світ» у клас і роблять процес викладання ефективнішим.

Отже, перевагами використання інновацій і нових технологій у освітньому процесі $е$ :

- більш швидкий розвиток комунікаційних навичок у порівнянні зі звичайними методами викладання;

- використання у процесі навчання серед студентів методу проб і помилок;

- забезпечення великої різноманітності методів вивчення мови;

- розвиток інтересу до процесу вивчення мови;

- стимулювання самодіяльності, самоосвіти і зниження френомену вербалізму;

- забезпечення якісного викладання, а також допомогу у подоланні мовних бар'єрів;

- економія часу, швидке і перманентне навчання [5, с. 67].

Таким чином, ми можемо зробити висновок, що інноваційні та освітні процеси є неподільними один від одного. Сучасна система освіти спрямована на максимальне використання інноваційних технічних засобів, щоб зробити процес навчання найефективнішим. Особливо цей процес важливий для викладання англійської мови. Технологічні засоби, у першу чергу, слугують опорою для самого викладача.

У процесі впровадження інновацій, а також використання нових технологій, дуже важливу роль відіграє особистість безпосередньо викладача. Для того, щоб отримати максимальний ефект від використання нових технологій в процесі викладання англійської мови, викладач повинен пам'ятати про те, що технологічні засоби - це тільки доповнення до уроку, але вони не можуть повністю замінити його особистість. В умовах різноманітності інновацій і технологій у процесі освіти, важливим елементом $є$ їх ретельний відбір і оцінка, бо застосування всіх інноваційних технологічних засобів у процесі викладання англійської мови є недоцільним і неможливим. Тільки після ретельного розгляду переваг і недоліків застосування певних технологічних засобів, вони можуть бути застосовані у процесі викладання мови. Отже, викладач повинен дотримуватися наступних критеріїв:

- стратегія викладання повинна відповідати рівню знань студентів;

- представлення матеріалу має бути чітким, точним і лаконічним;

- освітні матеріали повинні відповідати достатнъому для розуміння рівню складності для студентів; 
- технологічні засоби повинні виконувати виключно освітні фрункції (мотивація, надання інформації), але не бути відволікаючим від освітнього процесу елементом;

- освітній матеріал повинен пройти попередню перевірку викладачем на відсутність граматичних і орфографічних помилок;

- матеріали повинні бути актуальними і цікавими для студентів (Gower, 1995:98).

Основним завданням викладання англійської мови є розвиток 4 основних навичок: аудіювання, читання, комунікації та письма. Розглянемо окремо роль кожного навику і технологій, які можуть бути застосовані для їх розвитку та удосконалення.

1. Аудіювання (прослуховування тексту).

Аудіювання визначається як процес визначення та розуміння мови. Цей процес містить у собі розуміння та сприйняття інтонації мовця, граматичних конструкцій, лексики і розуміння загального змісту тексту [6, с. 73]. Студент повинен бути здатним поєднувати ці компоненти одночасно. Аудіювання розглядаеться як обов'язковий навик для вивчення англійської мови.. Існує безліч технологій для підвищення навичок аудіювання, а саме:

- використання комп'ютерів;

- телебачення (перегляд ТБ програм і прослуховування радіо);

- використання CD плеєрів, касетних магнітодронів і т.п.

2. Читання.

Читання є процесом розуміння письмового тексту учнем. Це важливий навик, який залежить від словникового запасу і загальних знань учня [6, с. 74].

$\mathrm{У}$ процесі читання текстів англійською мовою, студент може поліпшити свій словниковий запас, а також отримати нову інформацію, ідеї, які допоможуть значно підвищити загальний інтелект і знання студента.

Технології для розвитку навичок читання:

- використання комп'ютерних програм для читання текстів;

- мультимедійні технологіі;

- використання інтернет ресурсів;

- використання електронних словників.

3. Комунікащійні навички.

До інноваційних технологій, які сприяють розвитку комунікаційних навичок, належать:

- інтернет онлайн конференції;
- використання програм для записування

і відтворення голосу;

- програми для онлайн спілкування

4. Письмо.

Процес написання тексту може бути одним 3 найважчих для студентів, які вивчають англійську мову, так як вони повинні виконувати такі завдання як: генерування ідей, досконале використання граматики та лексики. До технічних засобів поліпшення навичок письма належать:

- використання комп'ютерів;

- написання е-mail листів;

- текстовий інтернет чат.

Проаналізовані нами аспекти використання інноваційних технологій у процесі викладання української мови дають можливість нам стверджувати, що:

1. 3 розвитком технологій, їх включення у процес навчання англійської мови стало обов'язковим.

2. Комп'ютер розглядається як складова частина навчальної діяльності, i як засіб, за допомогою якого, певні навички передаються учням.

3. Теорія і практика вивчення англійської мови можуть бути поєднані один з одним за рахунок використання сучасних технологій.

4. Викладачі англійської мови повинні залучати своїх студентів до використання нових технологій у процесі розвитку мовних навичок.

6. Навчальні заклади повинні модернізувати свої технічні можливості, надаючи необхідне обладнання і лабораторії для підтримки навчального процесу.

Висновки. Інноваційні технології стали невід'ємною частиною процесу викладання і вивчення англійської мови. Вони допомагають студентам за коротший час оволодіти потрібними навичками для вільного використання англійської мови, а саме: навички аудіювання, читання, письма та комунікації. 3 огляду на всю важливість інноваційних технологій, слід зазначити, що центральне місце у процесі викладання займає особистість вчителя, який обирає, оцінює і впроваджуе нові технології. Таким чином, технології допомагають викладачеві вирішити велику кількість технічних питань, зробити урок цікавішим, але технології не можуть замінити викладача повністю. Перспективою для подальших досліджень може стати аналіз інших інноваційних тенденцій у процесі викладання англійської мови.

\section{Список літератури:}

1. Городяненко В.Г. Социология : уч. для студ. высших уч. зав. Киев : Изд. центр «Академия», 2002.560 с.

2. Савченко А.Я. Дидактика начальной школы. Киев : Абрис, 1997. 420 c.

3. Bose M. A text book of English Language Teaching for Indian Students. Ch. New Century Book House, 2005.440 p.

4. Crystal D. English as a global language. Cambridge. Cambridge University Press. 2007. 253 p.

5. Gower R. Teaching Practice Handbook. L. Macmillan Heinemann, 1995. 334 p.

6. Kumar J. Studies in Language Testing 2. Cambridge. University Press, 1995. 150 p.

\section{References:}

1. Gorodyanenko V.G. (2002) Sotsiologiya: uch. dlya stud. vysshikh uch. zav. Kyiv: Izd. tsentr «Akademiya», 560 s. (in Russian)

2. Savchenko A.Ya. (1997) Didaktika nachalnoj shkoly. Kyiv: Abris, 420 s. (in Russian)

3. Bose M. (2005) A text book of English Language Teaching for Indian Students. Ch. New Century Book House, 440 p.

4. Crystal D. (2007) English as a global language. Cambridge. Cambridge University Press, $253 \mathrm{p}$.

5. Gower R. (1995) Teaching Practice Handbook. L. Macmillan Heinemann, 334 p.

6. Kumar J. (1995) Studies in Language Testing 2. Cambridge. University Press, 150 p. 